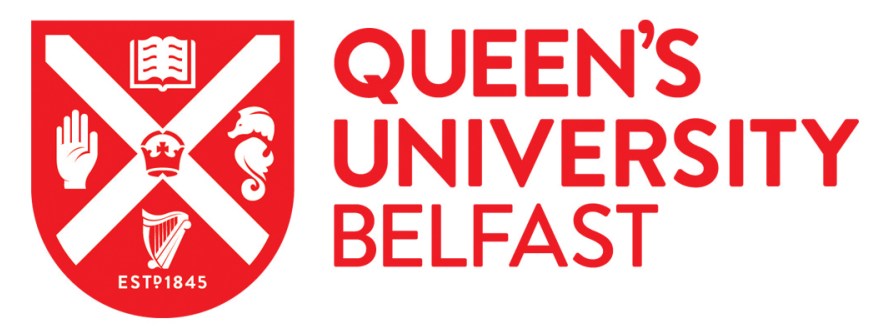

\title{
Impact of long-term storage at ambient temperatures on the total quality and stability of high-pressure processed tomato juice
}

Jayathunge, K. G. L. R., Grant, I. R., Linton, M., Patterson, M. F., \& Koidis, A. (2015). Impact of long-term storage at ambient temperatures on the total quality and stability of high-pressure processed tomato juice. Innovative Food Science and Emerging Technologies, 32, 1-8. https://doi.org/10.1016/j.ifset.2015.10.003

Published in:

Innovative Food Science and Emerging Technologies

Document Version:

Peer reviewed version

Queen's University Belfast - Research Portal:

Link to publication record in Queen's University Belfast Research Portal

Publisher rights

(c) 2015 Elsevier. This manuscript version is made available under the CC-BY-NC-ND 4.0 license http://creativecommons.org/licenses/by-ncnd/4.0/, which permits distribution and reproduction for non-commercial purposes, provided the author and source are cited.

\section{General rights}

Copyright for the publications made accessible via the Queen's University Belfast Research Portal is retained by the author(s) and / or other copyright owners and it is a condition of accessing these publications that users recognise and abide by the legal requirements associated with these rights.

Take down policy

The Research Portal is Queen's institutional repository that provides access to Queen's research output. Every effort has been made to ensure that content in the Research Portal does not infringe any person's rights, or applicable UK laws. If you discover content in the Research Portal that you believe breaches copyright or violates any law, please contact openaccess@qub.ac.uk. 


\section{Accepted Manuscript}

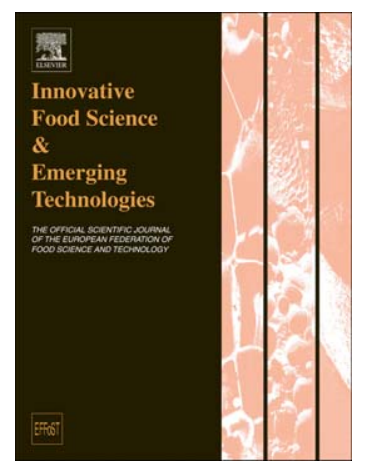

Impact of long-term storage at ambient temperatures on the total quality and stability of high pressure-processed tomato juice

K.G.L.R. Jayathunge, Irene R. Grant, Mark Linton, Margaret F. Patterson, Anastasios Koidis

PII:

S1466-8564(15)00195-2

DOI: doi: 10.1016/j.ifset.2015.10.003

Reference: INNFOO 1379

To appear in: $\quad$ Innovative Food Science and Emerging Technologies

Received date: 3 June 2015

Revised date: $\quad 19$ August 2015

Accepted date: 8 October 2015

Please cite this article as: Jayathunge, K.G.L.R., Grant, I.R., Linton, M., Patterson, M.F. \& Koidis, A., Impact of long-term storage at ambient temperatures on the total quality and stability of high pressure-processed tomato juice, Innovative Food Science and Emerging Technologies (2015), doi: 10.1016/j.ifset.2015.10.003

This is a PDF file of an unedited manuscript that has been accepted for publication. As a service to our customers we are providing this early version of the manuscript. The manuscript will undergo copyediting, typesetting, and review of the resulting proof before it is published in its final form. Please note that during the production process errors may be discovered which could affect the content, and all legal disclaimers that apply to the journal pertain. 
Impact of long-term storage at ambient temperatures on the total quality and stability of high pressure-processed tomato juice.

K. G. L. R. Jayathunge ${ }^{\mathrm{a}}$, Irene R. Grant ${ }^{\mathrm{a}}$, Mark Linton ${ }^{\mathrm{b}}$, Margaret F. Patterson ${ }^{\mathrm{b}}$, Anastasios Koidis $^{\mathrm{a}^{*}}$

a Institute for Global Food Security, Queen's University Belfast, Northern Ireland, UK.

${ }^{\mathrm{b}}$ Agri-Food and Biosciences Institute for Northern Ireland, Newforge Lane, Belfast, Northern Ireland, UK

Corresponding author:

Dr Anastasios (Tassos) Koidis

Institute for Global Food Security

Queen's University Belfast

18-30 Malone Road

Belfast, BT9 5BN

Northern Ireland, UK

Tel: +44 2890975569

email: t.koidis@qub.ac.uk 


\section{ABSTRACT}

High pressure processing (HPP) can produce tomato juice of high quality and safety with a short shelf life under refrigeration temperatures. Long-term higher temperature storage studies are rare and temperature tolerant products are challenging to develop. The effect of high pressure processing (HPP) on the total quality (colour, microbial counts, phytochemical levels, antioxidant and enzymatic activities) and stability (retention over time) of tomato juice during long-term storage was investigated. Thermal processing (TP) was used as a control treatment and overall, two different ambient conditions $\left(20^{\circ} \mathrm{C}\right.$ and $\left.28^{\circ} \mathrm{C}\right)$ were tested. Immediately after processing, HPP products proved superior to TP ones (enhanced redness, total carotenoids and lycopene, stable total phenols, and inactivation of pectin methyl esterase). During initial storage (30 d) most quality attributes of HPP juice remained stable. Prolonged storage, however, led to losses of most quality attributes, although HPP $\left(20^{\circ} \mathrm{C}\right)$ showed lower quality degradation rate constants comparison to TP and HPP $\left(28^{\circ} \mathrm{C}\right)$.

Keywords: tomato, high-pressure, thermal processing, nutritional, phytochemical, quality, storage 


\section{INTRODUCTION}

Tomato (Solanum lycopersicum L.) is the second most widely grown vegetable crop in many countries across the globe and is consumed in large quantities partly due to its nutritional, functional and health properties (Clinton, 1998; Takeoka, Dao, Flessa, Gillespie, Jewell, \& Huebner, 2001). Awareness of healthy eating has grown amongst modern consumers who are seeking nutrient dense and convenient foods such as tomato juice. Processing is essential to ensure the total quality of tomato juice and to maintenance or stabilise these qualities until consumption. Conventional processing techniques, such as heating, may induce undesirable changes in organoleptic properties and reduce the bioavailability of micronutrients (Patras, Brunton, Pieve, Butler, \& Downey, 2009). Non thermal processing technologies are emerging as alternatives which claim no compromise in safety while ensuring higher retention of important nutrients. There is an opportunity for the food industry, in particular tomato processors, to adapt and develop new safe products that guarantee unprecedented quality and 'freshness' characteristics.

As a non-thermal processing technique, high pressure processing (HPP) applies a pressure between 200-600 MPa to inactivate vegetative microorganisms, some enzymes and to preserve quality attributes. Many authors have assessed the effect of HPP on quality and micronutrients of tomato juice and purée in comparison to thermal processing (TP) and it has proved useful for preserving the quality of tomato juice and purée after treatment (Dede, Alpas, \& Bayindirli, 2007; Hsu, 2008; Krebbers, Matser, Hoogerwerf, Morzelaar, Momassen, \& Van den berg, 2003; Patras et al., 2009; Porretta, Birzi, Ghizzoni, \& Vicini, 1995; Sanchez-Moreno, Plaza, Ancos, \& Cano, 2006). Alongside nutrient retention inactivation of two enzymes, pectin methyl esterase (PME) and polygalacturonase (PG) is very important to maintain the desired viscosity of tomato juice and purée. Several researchers have investigated the effect of HPP on PME and PG activities at various temperatures (Boulekou, 
Mallids, Taoukis, \& Stoforos, 2011; Crelier, Robert, Claude, \& Juillerat, 2001; Fachin, Van Loey, Nguyen, Verlent, Indrawati, \& Hendrickx, 2003; Hsu, 2008; Krebbers et al., 2003; Verlent, Van Loey, Smout, Duvetter, \& Hendrickx, 2004) and they found total inactivation of PG and contradictory behaviour of PME at some pressure/temperature conditions (500$\left.800 \mathrm{MPa} / 20-90^{\circ} \mathrm{C}\right)$. Colour retention is also very important quality attribute of tomato juice. It is established that $\mathrm{pH}$ has an important effect on pigments and responsible for the colour of fruits and vegetables during processing (Andres-Bello, Barreto-Palacios, Garcia-Segovia, Mir-Bel, \& Martinez-Monzo, 2013) but the impact of reducing $\mathrm{pH}$ on the maintenance of tomato juice quality has not been widely investigated.

Maintaining quality and nutritional properties of tomato juice throughout long-term storage at higher temperatures is very challenging, but would be extremely useful especially for tropical countries of high ambient temperatures, where low temperature storage facilities are not adequately available, to preserve large quantities of tomatoes produced during the glut season. Surprisingly few researchers have reported the effect of HPP on quality attributes during long-term storage under such conditions and the results are contradictory. Gupta, Balasubramaniam, Schwartz, \& Francis (2010) claimed that HPP (500-700 MPa) can result in a microbiologically safe tomato juice product for 52 weeks at 25 and $37^{\circ} \mathrm{C}$ whereas Dede et al., 2007) showed more moderate results after 4 weeks at $25^{\circ} \mathrm{C}$ using much lower pressures (150-250 MPa). As well as microbiological stability, the fate of minor constituents and other crucial quality parameters of tomato juice during storage at ambient temperature have not been well studied. Only one study reported on the complete antioxidant activity, ascorbic acid content and colour degradation after HPP treatment, although only for limited amount of time (Dede et al, 2007). Their results showed better retention of ascorbic acid, antioxidant activity and colour than the conventional, thermally processed samples. The long-term, high temperature storage study of Gupta et al. (2010) considered some quality parameters (colour, 
lycopene content) and found better retention throughout storage compared to heat treatment, although the effect on other important nutritional parameters such as ascorbic acid, total phenol content and related antioxidant activities and enzyme activities that are essential in assessing the stability of long storage products was not addressed.

Most importantly, most of the HPP studies cited, including the two above, have been conducted using laboratory scale HPP equipment where the capacity is below 5 L. Results obtained using this type of experimental equipment may not necessarily reflect results acquired using industrial processors and usually significant charges are required for scaling up.

Therefore, studying the effect of HPP on the quality of tomato juice during long-term storage is an important consideration in evaluating novel processing methods in comparison to existing practices. The aim of this study was to evaluate the effects of industrial scale HPP on microbiological quality, appearance and nutrient retention of tomato juice in comparison to TP during long-term storage at two different ambient conditions $\left(20^{\circ} \mathrm{C}\right.$ and $\left.28^{\circ} \mathrm{C}\right)$. The effect of juice $\mathrm{pH}$ on the quality parameters was also investigated.

\section{MATERIALS AND METHODS}

\subsection{Materials}

All chemicals and standards except for nutrient agar and maximum recovery diluent (Oxoid, Basingstoke, UK) were purchased from Sigma Aldrich (Dorset, UK) and were of analytical grade. Fully ripe tomatoes (cv Pitenza, cultivated in Spain) were purchased at 3 different occasions from local stores in Northern Ireland (UK) between April to May 2013. In total, 45 $\mathrm{kg}$ of tomatoes were purchased and graded before processing (mean weight, $85 \pm 5 \mathrm{~g}$ and mean circumference, $15 \pm 1 \mathrm{~cm}$ ), odd shape and size tomatoes were excluded. Cheese cloth 
$(100 \times 100 \mathrm{~cm})$ was purchased in the local market and standard packaging materials (polyethylene/polyamide film) were obtained from Scobie \& Junor (Mallusk, UK).

\subsection{Sample preparation}

Tomatoes were washed, cut into pieces and blended using a household blender. The seeds and skin of the tomato were removed by passing the resulting juice through a cheese cloth. The juice was divided into three aliquots and the $\mathrm{pH}$ of one aliquot of tomato juice was altered to $\mathrm{pH} 3.93$ by adding citric acid. The $\mathrm{pH}$ of the other two aliquots was left unaltered, at the original $\mathrm{pH}$ of 4.3. Samples of juice $(50 \mathrm{ml})$ were transferred into polyethylene/polyamide pouches $(15 \times 10 \mathrm{~cm})$, heat sealed and kept under refrigeration $\left(4^{\circ} \mathrm{C}\right)$ until processing.

\subsection{High pressure (HP) and thermal processing (TP) and storage study design}

Tomato juices of altered and unaltered $\mathrm{pH}$ were blanched using hot break method at $90^{\circ} \mathrm{C}$ for 2 min (Hayes et al, 1998) using a water bath (Grant, GD 100, UK). The temperature of the juice during blanching was monitored using a digital thermometer (HI 98804, Hanna Instruments, UK) fitted with a k-type thermocouple and samples were cooled in iced water immediately after blanching. The samples for HPP were treated using an Avure Quintus 35L (Avure Technologies, Middletown, OH, USA) with a heat-controlled vessel and a capacity of $35 \mathrm{~L}$ (internal diameter: $18 \mathrm{~cm}$, length: $1.2 \mathrm{~m}$ ) and pressurised (600 MPa /1 min) at ambient temperature (approximately $16^{\circ} \mathrm{C}$ ). The temperature increase due to adiabatic heating was approximately $3^{\circ} \mathrm{C}$ per $100 \mathrm{MPa}$. Time taken to reach the target pressure was approximately 2 min and decompression took approximately10 sec. For comparison with conventional heat processing, heat sealed pouches of tomato juice were subjected to thermal processing using a water bath at $95^{\circ} \mathrm{C}$ for $20 \mathrm{~min}$ (Hayes, Smith, \& Morris, 1998), as described above. The entire 
experiment was conducted on three separate batches, on three consecutive days to produce three replicate samples.

HPP and TP samples were stored for up to 12 months at two different ambient temperature $\left(20^{\circ} \mathrm{C}\right.$ and $\left.28^{\circ} \mathrm{C}\right)$ conditions and analysed after $0,1 / 2,3 / 4,1,2,3,6,9$ and 12 months storage for microbial counts, colour, phytochemicals, antioxidant activity and enzyme activity. Phytochemicals, antioxidant activity and enzyme activity analyses were carried out on freezedried samples, taken at each sampling time but processed all at the same time (i.e. after 12 months). Freeze drying was achieved using a freeze dryer (Christ-Alpha 1-4 LD, Germany).

\subsection{Microbiological analysis}

Total viable count (TVC) was determined using Nutrient agar. Tomato juice $(1 \mathrm{ml})$ was aseptically transferred to $9 \mathrm{ml}$ maximum recovery diluent and serial dilutions prepared. Aliquots $(100 \mu \mathrm{l})$ of appropriate dilutions were spread plated on duplicate nutrient agar plates. After incubation at $30^{\circ} \mathrm{C}$ for $24 \mathrm{~h}$, colonies were counted and results were expressed as $\mathrm{CFU} / \mathrm{ml}$ of tomato juice.

\subsection{Colour measurements}

Colour was measured using a Konica Minolta portable colorimeter (CR-410, Japan). A standard white tile $(\mathrm{X}=87.01, \mathrm{Y}=0.3185, \mathrm{Z}=0.3365)$ was used to calibrate the instrument and $\mathrm{L}^{*}, \mathrm{a}^{*}$ and $\mathrm{b}^{*}$ values were directly taken from the colorimeter. The Hue value $(\mathrm{a} / \mathrm{b})$ and the overall colour change $\left(\Delta \mathrm{E}=\sqrt{ } \Delta \mathrm{L}^{2}+\Delta \mathrm{a}^{2}+\Delta \mathrm{b}^{2}\right)$ were calculated based on measured $\mathrm{L}^{*}, \mathrm{a}^{*}$ and $\mathrm{b}^{*}$ values.

\subsection{Quantification of total carotenoids and lycopene content}


Total carotenoids were determined according to Koca, Burdurlu, \& Karadeniz (2007) with some modifications. Freeze-dried tomato samples were extracted with hexane:acetone $(7: 3)$ $(0.5 \mathrm{~g} / 25 \mathrm{ml})$ and total carotenoids were quantified with colorimetric detection at $450 \mathrm{~nm}$ using UV-vis spectrophotometer (JENWAY 6305, UK) and $\beta$-carotene as a standard (0.5-10 $\mu \mathrm{g} / \mathrm{ml})$. Lycopene content was determined colorimetrically (472 $\mathrm{nm})$ using the method described by Sadler, Davis, \& Dezman (1990) after hexane:ethanol:acetone (2:1:1) extraction. Concentration of lycopene was calculated using the equation: $\mathrm{C}=\mathrm{A} \mathrm{x} 10^{4} / \mathrm{E}^{\%}{ }_{1 \mathrm{~cm}}$ $\mathrm{x} l$, where: $\mathrm{C}=$ lycopene concentration $(\mu \mathrm{g} / \mathrm{ml}), \mathrm{A}=$ absorbance at $472 \mathrm{~nm}, \mathrm{E}^{\%} 1 \mathrm{~cm}=$ extinction coefficient (3450 for lycopene in hexane) and $l$ the path length $(1 \mathrm{~cm})$.

\subsection{Quantification of total phenolic content}

The total phenolics were conventionally quantified colorimetrically using a modified FolinCiocalteu method (Singleton, Orthofer, \& Lamuela-Raventos, 1999). The reaction mixture, consisting of $125 \mu \mathrm{l}$ of methanolic tomato extract $(0.1 \mathrm{~g} / 10 \mathrm{ml}), 0.5 \mathrm{ml}$ of distilled water and $125 \mu \mathrm{l}$ of Folin-Ciocalteu reagent, was allowed to stand for 6 min before adding $1.25 \mathrm{ml}$ of a $7 \%$ sodium carbonate and final volume was adjusted to $3 \mathrm{ml}$ with distilled water. Absorbance was measured at $760 \mathrm{~nm}$, after 90 min and a standard curve was obtained with gallic acid (50$600 \mu \mathrm{M})$.

\subsection{Quantification of ascorbic acid}

Ascorbic acid content was determined according to the modified 2,6dichlorophenolindophenol (DIP) method (Klein and Perry, 1982). Freeze-dried samples were extracted with $1 \%$ metaphosphoric acid $(0.1 \mathrm{~g} / 10 \mathrm{ml})$ and centrifuged $(3000 \times \mathrm{g} / 15 \mathrm{~min})$ (SORVALL Legend RT, Germany). An aliquot of $0.5 \mathrm{ml}$ of the supernatant was added to 4.5 $\mathrm{ml}$ of $0.05 \mathrm{mM}$ DIP, mixed for $15 \mathrm{sec}$ and measured colorimetrically at $515 \mathrm{~nm}$. L-ascorbic acid was used as a standard $(0-400 \mu \mathrm{g} / \mathrm{ml})$. 


\subsection{Quantification of ABTS and ORAC antioxidant activities}

Antioxidant activities were measured using two methods. Firstly, the 2,2-azino-di-3ethylbenzothialozine-6-sulphonic acid diammonium salt (ABTS) decolouration method was applied with some modifications (Re, Bramley, \& Rice-Evans, 1999). Freeze-dried tomato powder was extracted with $80 \%$ ethanol $(0.25 \mathrm{~g} / 10 \mathrm{ml})$ and centrifuged $(3116 \times \mathrm{g} / 10 \mathrm{~min})$. The total antioxidant activity was measured in the supernatant. Absorbance readings were taken $1 \mathrm{~min}$ after initial mixing of the reaction mixture (sample extract $(10 \mathrm{ml})$ and $1.1 \mathrm{ml}$ $\mathrm{ABTS}^{+\bullet}$ ) and a standard curve was obtained using Trolox (100-800 $\left.\mu \mathrm{M}\right)$. For the oxygen radical absorption capacity (ORAC), the method of Huang, Ou, Hampsch-Woodill, Flanagan, \& Prior (2002) was used with some modifications. Appropriately diluted tomato extract (20 $\mu 1,0.05 \mathrm{~g} / 40 \mathrm{ml}, 80 \%$ methanol) and $8.16 \times 10^{-5} \mathrm{mM}$ fluorescein $(40 \mu \mathrm{l})$ solutions were loaded on a Greiner flat bottom 96 -well plate and pre-incubated for $30 \mathrm{~min}$ at $37^{\circ} \mathrm{C}$ within the plate reader (TECAN Safire2 monocromator). After incubation, $140 \mu 1$ of 0.5 M 2,2'-Azobis (2-methylpropionamidine) dihydrochloride (AAPH) solution was added and immediately the loss of fluorescence was followed at $1 \mathrm{~min}$ intervals for $100 \mathrm{~min}$. The standard curve was obtained using Trolox within the linear range of $0-64 \mu \mathrm{M}$ and all reagents were prepared using $75 \mathrm{mM}$ phosphate buffer (pH 7.4).

\subsection{Quantification of PME and PG enzymatic activities}

Pectin methyl esterase (PME) activity was assayed according to the method applied by Hagerman and Austin (1986) with modifications. Briefly, the enzyme was extracted $(0.25$ $\mathrm{g} / 10 \mathrm{ml}, 8.8 \% \mathrm{NaCl})$ from the freeze-dried tomato powder and centrifuged $(4369 \times \mathrm{g} / 25$ $\min )$. The extracted supernatant, reagents of citrus pectin solution $(0.5 \% \mathrm{w} / \mathrm{v}$ in $0.1 \mathrm{M} \mathrm{NaCl})$ and bromothymol blue indicator dye $(0.01 \% \mathrm{w} / \mathrm{v}$ in $0.003 \mathrm{M}$ potassium phosphate buffer, $\mathrm{pH}$ 7.5) were adjusted to $\mathrm{pH} 7.5$ using $\mathrm{NaOH}(1 \mathrm{M})$. Initial absorbance was measured after 
mixing the pectin solution $(1 \mathrm{ml})$ with $0.1 \mathrm{ml}$ of bromothymol blue and the decrease of absorbance $(620 \mathrm{~nm})$ at $30^{\circ} \mathrm{C}$ was recorded 5 min after adding the enzyme extract $(20 \mu \mathrm{l})$ to the mixture. D-galacturonic acid $(0-50 \mu \mathrm{M})$ was used to obtain a standard curve.

Polygalacturonase (PG) was extracted from the freeze-dried tomato powder using a modified method of Pressey (1986). The supernatant was adjusted to $\mathrm{pH} 4.4$ and assayed for PG activity using the method applied by Gross (1982). The reaction mixture, consisting of enzyme extract $(100 \mu \mathrm{l}), 0.2 \%$ polygalacturonic acid $(50 \mu \mathrm{l})$ and $50 \mathrm{mM}$ sodium acetate $(150$ $\mu \mathrm{l}$ ), was incubated at $30^{\circ} \mathrm{C}$ for $1 \mathrm{~h}$. Subsequently, $2 \mathrm{ml}$ borate buffer (pH 9) and $400 \mu \mathrm{l}$ of $1 \%$ cyanoacetamide were added to the reaction mixture, boiled for $10 \mathrm{~min}$ and the absorbance was measured at $276 \mathrm{~nm}$ after equilibrium at room temperature. D-galacturonic acid (0-250 $\mu \mathrm{M})$ was used to obtain a standard curve.

\subsection{Statistical analysis}

The data were statistically analysed by two-way ANOVA with SPSS 22 (IBM, UK) and means were compared using the Tukey post hoc test to explore which means are significantly different from each other. Statistical significance was accepted at a level of $95 \%$.

\section{RESULTS AND DISCUSSION}

\subsection{Microbial quality of tomato juice}

The mean TVC of the raw tomato juice was $6.69 \log _{10} \mathrm{CFU} / \mathrm{ml}$ and all HPP treatments (600 $\mathrm{MPa} / 1 \mathrm{~min})$ and thermal processing $\left(95^{\circ} \mathrm{C} / 20 \mathrm{~min}\right)$ were effective in reducing the $\mathrm{TVC}$ to below the detection limit $\left(<1 \log _{10} \mathrm{CFU} / \mathrm{ml}\right)$ as shown in Table 1 . Lower initial microbial populations (3.62 and $4.5 \log _{10} \mathrm{CFU} / \mathrm{ml}$ ) and similar behaviour after processing, albeit at lower pressures (500 MPa/10 min; $250 \mathrm{MPa} / 15 \mathrm{~min}$, respectively), were reported by Dade et 
al. (2007) and Hsu, Tan, \& Chi (2008). Krebbers et al. (2003) observed that HPP treatment up to $500 \mathrm{MPa}$ at ambient temperature was sufficient for moderate inactivation of naturally present microorganisms, but treatment at $700 \mathrm{MPa}$ was needed to reduce the natural microflora to below the detection limit. With regards to effect of storage, results showed that HPP $\left(600 \mathrm{MPa} / 1 \mathrm{~min} / 35^{\circ} \mathrm{C}\right.$ ) was effective in maintaining the microbial count below the detection limits throughout the storage period irrespective of storage temperature and juice $\mathrm{pH}$ (data not shown); the same situation was observed for thermal processing. Porretta et al. (1995) also tested tomato juice with different $\mathrm{pH}$ levels ranging from 4-5 and observed that HPP (500 $\mathrm{MPa} / 3 \mathrm{~min} / 25^{\circ} \mathrm{C}$ ) was sufficient to develop products with no microbes detected, irrespective of pH level. Daryaei \& Balasubramanium (2013) showed that inactivation of $B$. coagulans spores by a combination of pressure and high temperature is needed in order to develop an ambient-stable product. In the present study, the blanching treatment $\left(90^{\circ} \mathrm{C} / 2 \mathrm{~min}\right)$ conducted prior to HPP must have contributed to the maintenance of ambient-stable product. Gupta et al. (2010) created a product that was microbiologically stable after 52 weeks storage at high ambient temperatures $\left(25\right.$ and $\left.37^{\circ} \mathrm{C}\right)$, using $\mathrm{HPP}\left(700 \mathrm{MPa} / 10 \mathrm{~min} / 45^{\circ} \mathrm{C}\right)$ or pressureassisted thermal processing (PATP) $\left(600 \mathrm{MPa} / 10 \mathrm{~min} / 100^{\circ} \mathrm{C}\right)$ instead of blanching. Others have claimed microbiologically stable products after a short storage period (12 weeks at $37^{\circ} \mathrm{C}, 28$ days at $4^{\circ} \mathrm{C}, 8$ weeks at $4^{\circ} \mathrm{C}$ ) after treatment at $600 \mathrm{MPa} / 10 \mathrm{~min} / 75^{\circ} \mathrm{C}, 500 \mathrm{MPa} / 10$ $\min / 25^{\circ} \mathrm{C}$ and $700 \mathrm{MPa} / 2 \mathrm{~min} / 20^{\circ} \mathrm{C}$, respectively (Daryaei \& Balasubramanium, 2013; Hsu, 2008; Krebbers et al., 2003), using laboratory-scale equipment.

\subsection{Colour change of tomato juice}

An attractive red colour is one of the main quality characteristics of tomato products. The raw juice had the lowest redness $(\mathrm{a} / \mathrm{b})$ values, as a result of the typical pinkish red colour of tomato juice before processing (Table 1). $\Delta \mathrm{E}$ represents the change of juice colour in 
comparison to fresh juice and all processed samples showed higher redness values (large $\Delta \mathrm{E}$ values) due to the leakage of lycopene from broken cellulose structure of the tomato tissue during processing (Lin \& Chen, 2005). The instrumental colour results (Table 1) were in agreement with those of Krebbers et al. (2003) and Poretta et al. (1995) who also observed enhancement of the redness of tomato puree after processing. Furthermore, tomato juice with natural $\mathrm{pH}$ (4.3) subjected to HPP showed significant $(\mathrm{p}<0.05)$ red colour retention compared to the juice with the $\mathrm{pH}$ altered, which was also previously reported by Porretta et al. (1995). This is possibly due to the lower level of ascorbic acid content in the unaltered $\mathrm{pH}$ sample compared to the $\mathrm{pH}$ altered, which is involved in the non-enzymatic browning reaction in tomato juice (Mudahar, Sidhu, \& Minhas, 1986). All treatments were equally ineffective to retain the initial colour of tomato juice, resulting in brown coloured products after 12 month period; this was more intense in TP samples and in samples stored at $28^{\circ} \mathrm{C}$. In contrast, Gupta et al. (2010) observed better colour retention of HP and PATP samples compared to TP samples during storage ( 52 weeks at 4,25 and $37^{\circ} \mathrm{C}$ ), but this may have been due to vacuum packaging. The kinetic behaviour of the colour characteristics of tomato juice samples throughout storage was determined. The change of redness as a function of storage time was described by a first-order kinetic model with high determination coefficients $\left(\mathrm{R}^{2}=0.97-0.79\right)$. The first order model rate constants ranged from $0.0735\left(\mathrm{TP}\right.$ at $\left.28^{\circ} \mathrm{C}\right)$ to $0.0348(\mathrm{HPP}, \mathrm{pH}$ 3.93 at $20^{\circ} \mathrm{C}$ ), emphasising higher red colour degradation in TP samples and the effectiveness of reducing the $\mathrm{pH}$ in tomato juice (lower rate constants were obtained for the $\mathrm{pH}$-altered samples). The pattern of colour change $(\Delta \mathrm{E})$ in $\mathrm{pH}$-altered HPP juice was not significantly different for the two storage temperatures for up to 9 months of storage, while both the juice with unaltered $\mathrm{pH}$ that had been treated with HPP and the TP samples showed significant differences between storage temperatures after 3 months of storage (Figure 1). The redness $(\mathrm{a} / \mathrm{b})$ of tomato juice can be correlated with lycopene content throughout storage, and the 
change in red colour as a function of lycopene and carotenoid content is fairly linear (Pearson coefficients 0.85 and 0.80 , respectively) (Table 2). Krebbers et al. (2003) reported little dependence on change in lycopene concentration for instrumental colour, in samples processed by thermal and combined pressure-thermal treatments.

\subsection{Phytochemicals retention after processing and during storage}

\subsubsection{Ascorbic acid content}

Ascorbic acid (vitamin C), as well as an indicator of the nutritional quality in fruit juices can be used as benchmark for the retention of other micronutrients during processing and storage because it is the most heat labile vitamin. The fresh (raw) tomato juice was found to be very rich in ascorbic acid containing $330.8 \pm 4.5 \mathrm{mg} / 100 \mathrm{~g}$ (Table 1 ), which degraded rapidly after processing and during storage. In fact, ascorbic acid levels were shown to be much more susceptible to degradation than any other nutrient in the present study. Immediately after processing, HPP treatments of both 4.3 and $3.93 \mathrm{pH}$ samples provided significantly $(\mathrm{p}<0.05)$ better ascorbic acid retention (66 and 69\%, respectively) compared to TP (57\%) (Table 1). Similar results have been reported by Hsu et al. (2008) and Sanchez-Moreno et al. (2006). Even higher retention (>90\%) was claimed in low (250 MPa) (Dede et al. (2007) and high (600 MPa) pressure treated juices (Patras et al., 2009). Processing losses are highly dependent on the HPP equipment, conditions and blanching procedures, if used. The low retention of ascorbic acid in this study is most likely due to the blanching treatment $\left(90^{\circ} \mathrm{C} / 2 \mathrm{~min}\right)$ that was applied prior to HPP. These losses may have been exacerbated by the equipment used (water bath) leading to long come-up times to reach the target temperature.

During long-term storage, substantial depletion of ascorbic acid was observed during the first 4 weeks in all treatments resulting in very low retention (4\%) at the end of storage (Table 3). The latter might be due to the presence of residual oxygen in the packaged juice (Lin \& Chen, 
2005). The rate constants, obtained from the developed first order kinetic model, which was fairly linear $\left(\mathrm{R}^{2}>0.75\right)$, varied from $0.2757\left(\mathrm{TP}\right.$, at $\left.20^{\circ} \mathrm{C}\right)$ to $0.3761\left(\mathrm{HPP}, \mathrm{pH} 3.9\right.$ at $\left.20^{\circ} \mathrm{C}\right)$. Higher ascorbic acid retention in unaltered $\mathrm{pH}$ samples, in comparison to altered $\mathrm{pH}$, could be observed at the end of storage. This is also confirmed by the obtained lower rate constants (Table 4). Similar long term studies could not be found in the literature. Dede et al. (2007) reported 70 and $45 \%$ ascorbic acid retention in HPP tomato juice after only 30 days of storage at 4 and $25^{\circ} \mathrm{C}$, respectively. Hsu et al. (2008) observed more stable ascorbic acid content $(70 \%)$ during 28 days chill storage. In the present study between 8 and $19 \%$ of ascorbic acid was retained over the same time period might be due to the accelerated oxidation rates at higher storage temperatures.

\subsubsection{Total phenol content}

Phenols appeared to be relatively resistant to the effects of processing, with the exception of HPP/unaltered $\mathrm{pH}$ tomato juice, which had a total phenol content of $4.83 \mathrm{mg}$ gallic acid/g, representing a significant difference $(\mathrm{p}<0.05)$ from fresh juice $($ Table 1$)$. This agrees with Dewanto, Wu, Adom, \& Liu (2002), who also observed that total phenol content did not change during processing. In contrast, Patras et al. (2009) observed a significant increase in phenol content in tomato after HPP (600 MPa/15 min). Here, long-term storage TP samples (at $28^{\circ} \mathrm{C}$ and $20^{\circ} \mathrm{C}$ ) resulted in higher rate constants $(0.0631$ and 0.0552 , respectively) in comparison to HPP samples, according to the developed first order kinetic model (Table 3). Higher total phenol content could be observed after 6 months storage $\left(28^{\circ} \mathrm{C}\right)$ in $\mathrm{HPP} /$ unaltered $\mathrm{pH}$ tomato juice samples with the lowest rate constant $(0.0454)$, when contrasted with the HPP/ altered $\mathrm{pH}$ samples (rate: 0.0490). Similar behaviour was noticed in the treatments stored at $20^{\circ} \mathrm{C}$. All treatments, however, were effective in retaining a total phenol content of more than $50 \%$ at the end of 12 month storage (Table 3). In another study, tomato juice treated at $90^{\circ} \mathrm{C}$ for 30 and $60 \mathrm{sec}$ also retained the initial total phenol content for a 
period of 2 and 3 weeks, respectively, at $4^{\circ} \mathrm{C}$ (Odriozola-Serrano, Solivia-Fortuny, \& MartinBelloso, 2008). Maintenance of total phenol content during long-term storage might be due to the inactivation of the enzymes responsible for their degradation.

\subsubsection{Total carotenoid and lycopene content}

Prior to processing, total carotenoid and lycopene content of raw tomato juice were 83.7 and $34.9 \mathrm{mg} / 100 \mathrm{~g}$, respectively (Table 1), which are typical values for this product (Krebbers et al., 2003). After TP and HPP (at $\mathrm{pH} 4.3$ and 3.93), total carotenoid contents were significantly increased by $255 \%, 197 \%$ and $278 \%$, respectively. These results were higher than those reported by Patras et al. (2009) who observed 172\% increases in total carotenoid contents using similar pressures. Hsu et al. (2008) observed no change in total carotenoids in TP samples and $60 \%$ increase in HPP samples. It has been reported that HP treatment is effective in enhancing the lycopene content (Krebbers et al., 2003) and the total carotenoid content (Sanchez-Moreno et al., 2006) of tomato purée. This enhancing effect has been attributed to pressure-induced extraction, as a result of effects on the membranes in plant cells (Shi \& Le Maguer, 2000). During long-term storage of the tomato juice, carotenoid and lycopene content depleted substantially (>35\%) within the first four weeks irrespective of treatment. This agrees with Gupta et al. (2010) who reported rapid degradation of lycopene during the first 5 weeks of storage. The degradation was more severe at $28^{\circ} \mathrm{C}$, as confirmed by higher rate kinetics obtained for both carotenoids $\left(>0.3739\right.$ for $28^{\circ} \mathrm{C}$ and $<0.2783$ for $20^{\circ} \mathrm{C}$ ) and lycopene $\left(>0.1819\right.$ for $28^{\circ} \mathrm{C}$ and $<0.1511$ for $\left.20^{\circ} \mathrm{C}\right)$ using the existing experimental data (Table 4). HPP-treated tomato juice stored at $20^{\circ} \mathrm{C}$ retained a higher total carotenoid content $(>18 \%)$ compared to all the other treatments, which resulted in less than $11 \%$ retention at the end of 12 month storage. With regards to the effect of $\mathrm{pH}$, tomato juice samples behaved in different ways at two temperature conditions: $\mathrm{pH}$ altered samples showed higher rate constants for total carotenoids and lycopene contents at $28{ }^{\circ} \mathrm{C}$ and $20{ }^{\circ} \mathrm{C}$, 
respectively. while, $\mathrm{pH}$ unaltered samples showed higher rate constants for total carotenoids and lycopene contents at $20^{\circ} \mathrm{C}$ and $28{ }^{\circ} \mathrm{C}$, respectively (Table 4). The loss of carotenoids during storage may be explained by isomerisation or oxidative degradation due to the presence of residual oxygen in the sample (Lin \& Chen, 2005).

\subsection{Antioxidant activity of tomato juice extracts}

HPP successfully retained antioxidant activity, as assessed by ABTS, without significant change, while TP resulted in a significant decrease of $15 \%(\mathrm{p}<0.01)$ during processing, in comparison to raw tomato juice (Table 1). Dede et al. (2007) and Sanchez-Moreno et al. (2006) also reported that total scavenging activity (DPPH) in tomato purée and juice was unaffected after HPP (400 MPa $/ 15 \mathrm{~min} / 25^{\circ} \mathrm{C}$ and $\left.250 \mathrm{MPa} / 15 \mathrm{~min} / 35^{\circ} \mathrm{C}\right)$, while Patras et al. (2009) observed increased antioxidant activity after HPP (600 MPa). The antioxidant activity of tomato juices was substantially depleted during the first few weeks of storage but then decreased more slowly, reaching values of $>322 \mu \mathrm{M} / 100 \mathrm{~g}$ in all treatments at 12 month storage (data not shown). The developed first order kinetic model predicted the antioxidant activity based on the ABTS well, as indicated by determination coefficients $\left(\mathrm{R}^{2}=0.79\right.$ to 0.95). In contrast to other quality parameters, the best retention (more than $35 \%$ ) of antioxidant activity was seen in the $\mathrm{pH}$ unaltered juice $(\mathrm{pH} 4.3)$, treated with HPP and stored at $20^{\circ} \mathrm{C}$ with the lowest rate constant $\left(0.0999, \mathrm{R}^{2}=0.85\right)$. On the other hand, $\mathrm{pH}$ altered tomato juice showed higher retention in antioxidant activity $(377 \mu \mathrm{M} / 100 \mathrm{~g})$ with lower rate constant $\left(0.1139, \mathrm{R}^{2}=0.79\right)$ after 12 months storage at $28^{\circ} \mathrm{C}$ in comparison to the values of the $\mathrm{pH}$ unaltered juice sample (Table 4). In practical terms, antioxidant activity in tomato products relates to the vitamin $\mathrm{C}$, polyphenols, vitamin $\mathrm{E}$ and carotenoids contents (Takeoka et al., 2001). In this study positive strong correlations (>0.87) were found between ABTS and ascorbic acid, total phenol, total carotenoids and lycopene in all treatments during storage 
(Table 2). This implies that the decrease in total antioxidant activity is mainly attributed to the decrease in all of these nutrients during storage. Dede et al. (2007) also demonstrated 20 and $70 \%$ loss of antioxidant activity in HPP and TP tomato juices respectively, during 30 days storage at 4 and $25^{\circ} \mathrm{C}$.

With regards to the ORAC assay, the raw juice had the highest antioxidant value (4084.8 $\mu \mathrm{M} / 100 \mathrm{~g})$ and this was significantly reduced $(\mathrm{p}<0.01)$ in all processed samples (Table 1$)$. The first order kinetic model poorly fitted the antioxidant capacity based on ORAC as indicated by low determination coefficients $\left(\mathrm{R}^{2}=0.15\right.$ to 0.07$)$. However, it showed higher rate constants for $28{ }^{\circ} \mathrm{C}$ stored $\mathrm{HP}$ treated samples in comparison to those stored at $20^{\circ} \mathrm{C}$. Furthermore, lower rate constants showed $\mathrm{pH}$ unaltered juice at $28^{\circ} \mathrm{C}$ and $\mathrm{pH}$ altered juice at $20^{\circ} \mathrm{C}$ (Table 4). ORAC results correlated with the ascorbic acid and total phenol content (0.97 and 0.77), but not with total carotenoids and lycopene contents. Lipophylic compounds such as lycopene are responsible for lipophylic antioxidant activity in tomatoes, but their contribution to total antioxidant activity is considered low (Wu, Beecher, Holden, Haytowitz, Gebhardt, \& Prior, 2004). Different ORAC and ABTS antioxidant activities were found in this study for all juice samples which is expected because they are based on a different principle (Frankel \& Meyor, 2000). Thus, the correlation between ORAC and ABTS was poor (0.28) demonstrating how a single assay is not sufficient to evaluate the total antioxidant activity. Changes in antioxidant activity, measured by ORAC, were not significant in all samples throughout the storage and very poor correlations were shown between ORAC values and nutritional parameters (Table 2). The antioxidant activity remained above 1166 $\mu \mathrm{M} / 100 \mathrm{~g}$ after 12 month storage period (data not shown).

\subsection{Enzyme activity}


Inactivation of pectin methyl esterase (PME) is desirable for cloudy juices to prevent the enzyme acting on pectin present in the food matrix, leading to a loss of cloud. Raw tomato juice showed high enzyme activity and all of the processing methods caused a decrease in the activity; 94.3, 91.2 and 97.5\%, respectively, in TP and HPP (pH 4.3 and 3.93) samples (Table 1). These results agree with those of De Sio, Dipollina, Villari, Loiudice, Laratta, \& Castaldo (1995) who reported efficient inactivation of tomato PME by thermal treatment $\left(88^{\circ} \mathrm{C} / 20\right.$ sec). In contrast, some researchers have observed increased PME activity in un-blanched tomato juice after HPP (Boulekou et al., 2011; Hernandez \& Cano, 1998; Hsu, 2008; Krebbers et al., 2003), while Hsu et al., 2008 have reported efficient inactivation by using low pressure-mild temperature. In the present study the residual PME activity of treated tomato juice remained constant during storage with few fluctuations (data not shown) and samples treated with TP and HPP $(\mathrm{pH} 3.93)$ and stored at $28^{\circ} \mathrm{C}$, maintained the highest $(<11$ $\%)$ and lowest $(<2.5 \%)$ residual activities, respectively, throughout storage. This more stabilised behaviour of PME activity during storage was well described by the poor determinant coefficients $\left(\mathrm{R}^{2}=0.53-0.06\right)$ of the first order kinetic model. Aguilo-Aguayo, Solivia-Fortuny, \& Martin-Belloso (2008) also observed stabilised 14\% residual activity in tomato juice throughout storage $\left(77\right.$ days at $\left.4^{\circ} \mathrm{C}\right)$.

On the other hand, polygalacturonase activity (PG) was found to be more stable to both thermal and pressure treatments than PME. TP resulted in a significant reduction (26\%) after tomato juice processing while HPP treatments caused a small but non-significant decrease in PG activity (Table 1). Crelier et al. (2001) also found a smaller inactivation of PG by heat $\left(60-105^{\circ} \mathrm{C}\right)$ while complete and more than $98 \%$ inactivation of PG by hot break treatment has also been reported; $93^{\circ} \mathrm{C}, 3 \mathrm{~min}$ (Fachin et al., 2003) and 95 ${ }^{\circ} \mathrm{C}, 2 \mathrm{~min}$ (Boulekon et al., 2011). PG is present in tomato fruit in two forms (PG1 and PG2) and depending on the extraction method used, a different ratio of PG 1 and PG2 is often obtained, with different overall 
thermal stability (Crelier et al., 2001). Literature emphasises the pressure resistance of PG at certain temperatures is due to reversible configuration of the enzyme (Fachin et al., 2003; Krebbers et al., 2003). Hsu (2008) reported 12 and 98\% PG activity reduction at $250 \mathrm{MPa}$ and 400-600 MPa, respectively. Furthermore, PG in tomato-based products could be totally inactivated at some pressure/temperature combinations; 500-550 $\mathrm{MPa} / 60-75^{\circ} \mathrm{C}$ (Fachin et al., 2003; Verlent et al., 2004). Here, significant inactivation of PG activity was found in all treatments during long-term storage, irrespective of processing method and temperature (data not shown). Aguilo-Aguayo et al. (2008) also observed decaying PG activity in tomato juice during storage at $4^{\circ} \mathrm{C}$ for 77 days.

\section{CONCLUSIONS}

Our results highlight the importance of high pressure processing (HPP) in comparison to conventional thermal processing (TP) in order to retain quality and most of the important tomato juice micronutrients, while resulting in a microbiologically stable product. However, the maintenance of these favourable properties over long-term elevated temperature storage is challenging due to stability issues over time. First order kinetics model revealed that nutrients decayed at a higher rate at $28^{\circ} \mathrm{C}$ in comparison to $20^{\circ} \mathrm{C}$, and altering of juice $\mathrm{pH}$ positively affected colour preservation but negatively affected ascorbic acid retention during storage, which uniquely shows the complexity of the chemical and biochemical phenomena occurring during storage of a fresh product. HPP technology, in combination with blanching, could be a viable alternative to conventional thermal treatment for tomato juice when an ultra-high quality and nutritious product is expected. Furthermore, the results of this study could be of economic importance for the tomato juice processors by supporting the development of new added-value products which are stable in ambient temperatures and, in turn, reduce refrigeration costs under specific conditions. Nevertheless, further research is needed in order 
to maintain a wider range of quality attributes after processing and during long-term storage especially if high ambient temperature tolerant products $\left(\geq 28^{\circ} \mathrm{C}\right)$ are required in specific parts of the world.

\section{Acknowledgements}

K. G. L. R. Jayathunge is in receipt of a PhD studentship from the Commonwealth Scholarship Commission, UK. The authors would like to thank the Commission for funding this research and Dr. Declan Devlin, AFBI, Belfast for providing access to the Minolta colorimeter for the colour measurements.

\section{REFERENCES}

Aguilo-Aguayo, I., Solivia-Fortuny, R., \& Martin-Belloso, O. (2008). Comparative study on colour, viscosity and related enzymes of tomato juice processed by pulsed electric fields or heat treatment. European Food Research and Technology, 227, 599-606.

Andres-Bello, A., Barreto-Palacios, V., Garcia-Segovia, P., Mir-Bel, J., \& Martinez-Monzo, J. (2013). Effect of pH on colour and texture of food products. Food Engineering Reviews, 5, 158-170.

Boulekou, S., Mallids, C., Taoukis, P.S., \& Stoforos, N.G. (2011). Quality evaluation of slightly concentrated tomato juice produced under high pressure conditions. Procedia Food Science, 1, 800-804.

Clinton, S. K. (1998). Lycopene: chemistry, biology, and implications for human health and disease. Nutrition Reviews, 56, 35-51.

Crelier, S., Robert, M.C., Claude, J., \& Juillerat, M.A. (2001). Tomato (Lycopersicum esculentum) pectin methyl esterase and polygalacturonase behaviors regarding heat and 
pressure induced inactivation. Journal of Agriculture and Food Chemistry, 49, 55665575 .

Daryaei, H., \& Balasubramanium, V.M. (2013). Kinetics of Bacillus coagulans spore inactivation in tomato juice by combinrd pressure-heat treatment. Food Control, 30, $168-175$.

De Sio, F., Dipollina, G., Villari, G., Loiudice, R., Laratta, B., \& Castaldo, D. (1995). Thermal resistance of pectin methyl esterase in tomato juice. Food Chemistry, 52, 135138.

Dede, S., Alpas, H., \& Bayindirli, A. (2007). High hydrostatic pressure treatment and storage of carrot and tomato juices: Antioxidant activity and microbial safety. Journal of the Science of Food and Agriculture, 87, 773-782.

Dewanto, V., Wu, X., Adom, K.K., \& Liu, R.H. (2002). Thermal processing enhances the nutritional value of tomatoes by increasing total antioxidant activity. Agricultural and Food Chemistry, 50, 3010-3014.

Fachin, D., Van Loey, A.M., Nguyen, B.L., Verlent, I., Indrawati, \& Hendrickx, M.E. (2003). Inactivation kinetics of polygalacturonase in tomato juice. Innovative Food Science and Emerging Technologies, 4, 135-142.

Frankel, E.N., \& Meyor, A.S. (2000). The problems of using one-dimensional methods to evaluate multifunctional food and biological antioxidants-A review. Journal of the science of Food and Agriculture, 80, 1925-1941.

Gross, K.C. (1982). A rapid and sensitive spectrophotometric method for assaying polygacturonase using 2-cyanoactamide. HortScience, 17(6), 933-934.

Gupta, R., Balasubramaniam, V.M., Schwartz, S.T., \& Francis, D.M. (2010). Storage stability of lycopene in tomato juice subjected to combined pressure-heat treatments. Journal of Agricultural and Food Chemistry, 58, 8305-8313. 
Hagerman, A.E., \& Austin, P.J. (1986). Continuous spectrophotometric for plant pectin methyl esterase. Journal of Agricultural Food Chemistry, 34, 440-444.

Hayes, W.A., Smith P.G., \& Morris, A.E.J. (1998). The production and quality of tomato concentrates. Critical Reviews in Food Science and Nutrition. 38(7), 537-564.

Hermandez, A., \& Cano, M.P. (1998). High pressure and temperature effects on enzyme inactivation in tomato puree. Journal of Agricultural Food Chemistry, 46, 266-270.

Hsu, K., Tan, F., \& Chi, H. (2008). Evaluation of microbial inactivation and physicochemical properties of pressurised tomato juice during refrigerated storage. LWT Food Science and Technology, 41, 367-375.

Hsu, K. (2008). Evaluation of processing qualities of tomato juice induced by thermal and pressure processing. LWT Food Science and Technology, 41, 450-459.

Huang, D., Ou, B., Hampsch-Woodill, M., Flanagan, J. A., \& Prior, R. L. (2002). Highthroughput assay of oxygen radical absorbance capacity (ORAC) using a multichannel liquid handling system coupled with a microplate fluorescence reader in 96-well format. Journal of Agricultural and Food Chemistry, 50, 4437 - 4444.

Klein, B. P., \& Perry, A. K. (1982). Ascorbic acid and vitamin A activity in selected vegetables from different geographical areas of the United States. Journal of Food Science, 47, 941-945, 948.

Koca, N., Burdurlu, H.S., \& Karadeniz, F. (2007). Kinetics of colour changes in dehydrated carrots. Journal of Food Engineering, 78, 449-455.

Krebbers, B., Matser, A.M., Hoogerwerf, S.W., Morzelaar, R., Momassen, M.M.M., \& Van den berg, R.W. (2003). Combined high pressure and thermal treatments for processing of tomato puree; Evaluation of microbial inactivation and quality parameters. Innovative Food Science and Emerging Technologies, 4, 377-385. 
Lin, C.H., \& Chen, B.H. (2005). Stability of carotenoids in tomato juice during storage. Food Chemistry, 90, 837-846.

Mudahar, G.S., Sidhu, J.S., \& Minhas, K.S. (1986). Technical note: Effect of low pH preservation on the colour and consistency of tomato juice. International Journal of Food Science and Technology, 21, 233-238.

Odriozola-Serrano, I., Solivia-Fortuny, R., \& Martin-Belloso, O. (2008). Changes of healthrelated compounds throughout cold storage of tomato juice stabilized by thermal or high intensity pulsed electric field treatments. Innovative Food Science and Emerging Technologies, 9, 272-279.

Patras, A., Brunton, N., Pieve, S.D., Butler, F., \& Downey, G. (2009). Effect of thermal and high pressure processing on antioxidant activity and instrumental colour of tomato and carrot purees. Innovative Food Science and Emerging Technologies, 10, 16-22.

Porretta, S., Birzi, A., Ghizzoni, C., \& Vicini, F. (1995). Effect of ultra high hydrostatic pressure treatments on the quality of tomato juice. Food Chemistry, 52, 35-41.

Pressey, R. (1986). Extraction and assay of tomato polygalacturonases. HortScience, 21, 490492.

Re, R., Bramley, P.M., \& Rice-Evans, C. (2002). Effects of food processing on flavonoid and lycopene status in a Mediterranean tomato variety. Free Radical Research, 36(7), 803-810.

Sadler, G., Davis, J., \& Dezman, D. (1990). Rapid extraction of lycopene and $\beta$-carotene from reconstituted tomato paste and pink grapefruit homogenates. Journal of Food Science, 55(5), 1460-1461.

Sanchez-Moreno, C., Plaza, L, Ancos, B., \& Cano, M.P. (2006). Impact of high-pressure and traditional thermal processing of tomato puree on carotenoids, vitamin $\mathrm{C}$ and antioxidant activity. Journal of the Science of Food and Agriculture, 86(2), 171-179. 
Singleton, V.L., Orthofer, R., \& Lamuela-Raventos, R.M. (1999). Analysis of total phenols and other oxidation substrates and antioxidants by means of Folin-Ciocalteu reagent. Methods in Enzymology, 299, 152-178.

Shi, J., \& Le Maguer, M. (2000). Lycopene in tomatoes: chemical and physical properties affected by food processing. Critical Reviews in Food Science and Nutrition, 40(1), 142.

Takeoka, G.R., Dao, L., Flessa, S., Gillespie, D.M., Jewell, W. T., \& Huebner, B. (2001). Processing effect on lycopene content and antioxidant activity of tomatoes. Journal of Agriculture and Food Chemistry, 49, 3713-3717.

Verlent, I., Van Loey, A., Smout, C., Duvetter, T., \& Hendrickx, M.E. (2004). Purified tomato polygalacturonase activity during thermal and high pressure treatment. Biotechnology and Bioengineering, 86(1), 63-71.

Wu, X., Beecher, G.R., Holden, J.M., Haytowitz, D.B., Gebhardt, S.E., \& Prior, R.L. (2004). Lipophilic and hydrophilic antioxidant capacities of common foods in the United States. Journal of Agricultural Food Chemistry, 52, 4026-4036. 

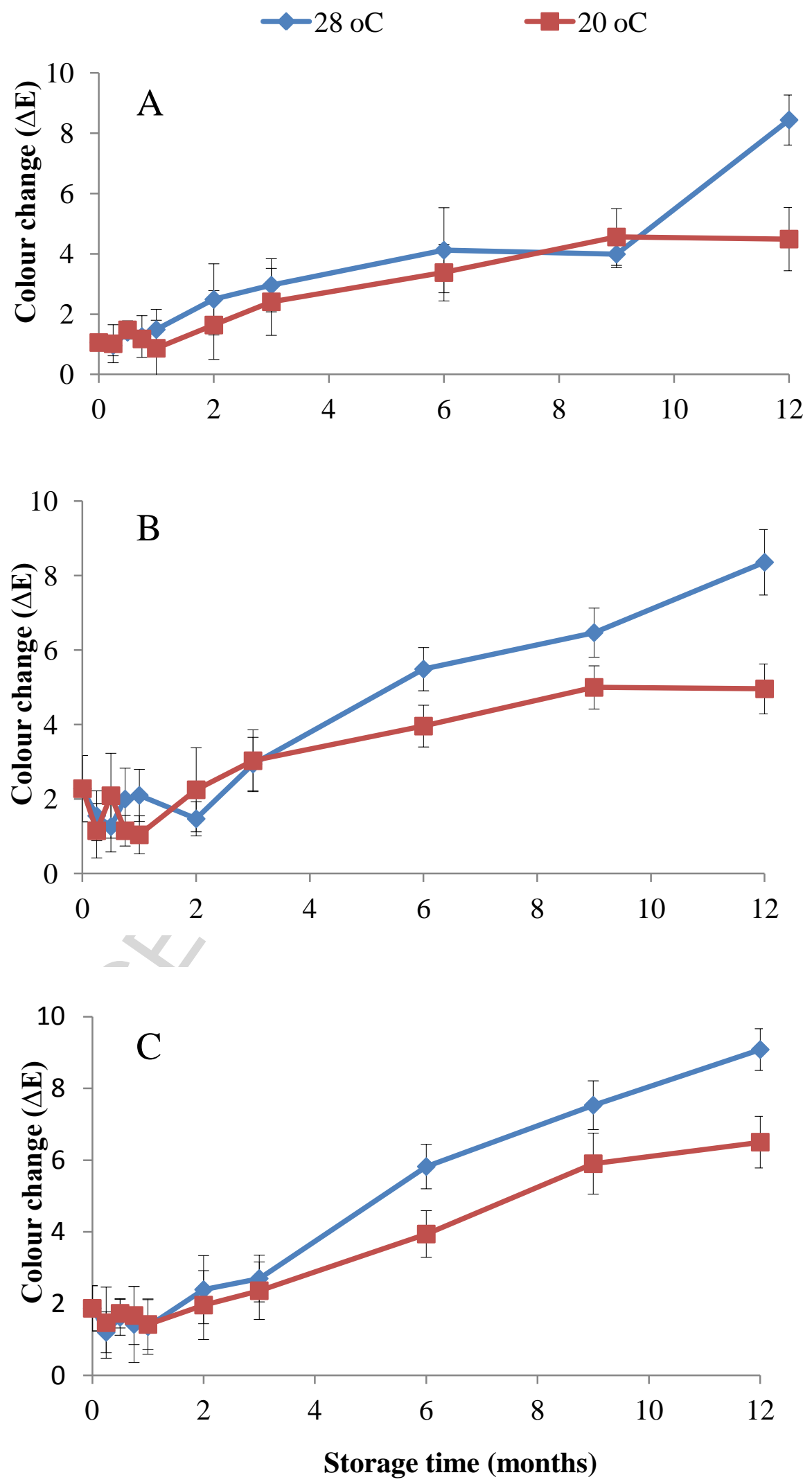

Figure 1: Effect of temperature on colour change of high pressure processed $\mathrm{pH}$ altered $(\mathrm{pH}$ 3.93 (A), unaltered ( $\mathrm{pH} 4.3$ ) (B) and thermally processed (C) tomato juice during storage. 
Table 1. Initial effects of thermal and high pressure processing on microbial levels, colour, nutritional quality, and antioxidant and enzymatic activities of tomato juice.

\begin{tabular}{lll}
\hline Parameter assessed & Raw juice & Treatment applied
\end{tabular}

TP $\quad$ HPP (pH 4.3) $\quad$ HPP ( $\mathrm{pH} 3.9)$

\section{MICROBIAL LEVELS}

TVC $(\log \mathrm{cfu} / \mathrm{ml})$

$6.69 \pm 0.01 \mathrm{a}$

$<2.00 \pm 0.00 \mathrm{~b}$

$<2.00 \pm 0.00 \mathrm{~b}$

$<2.00 \pm 0.00 \mathrm{~b}$

COLOUR

Lightness ( $\mathrm{L}$ value)

Redness $(\mathrm{a} / \mathrm{b})$

Total colour difference $(\Delta \mathrm{E})$

PHYTOCHEMICAL LEVELS

Ascorbic acid (mg/100 g)

Total phenol content

(mg gallic acid/g)

Total carotenoid

(mg $\beta$-carotene/100g)

Lycopene (mg /100g)

ABTS $(\mu \mathrm{M}$ Trolox/100 g)

\section{ANTIOXIDANT ACTIVITY}

$32.76 \pm 0.34 \mathrm{ab}$

$1.39 \pm 0.09 \mathrm{~b}$

$1.51 \pm 0.08 \mathrm{ab}$

$1.66 \pm 0.05 \mathrm{a}$

$1.46 \pm 0.01 \mathrm{~b}$

$0.00 \pm 0.00 \mathrm{~b}$

$1.87 \pm 0.63 \mathrm{a}$

$\mathrm{d} 2.28 \pm 0.89 \mathrm{a}$

$1.06 \pm 0.11 \mathrm{ab}$
$330.7 \pm 4.5 \mathrm{a}$

$6.5 \pm 0.8 \mathrm{a}$

$5.1 \pm 0.4 \mathrm{ab}$

$4.8 \pm 0.5 b$

$6.1 \pm 0.2 \mathrm{ab}$

$83.7 \pm 12.9 \mathrm{c}$

$213.7 \pm 13.7 \mathrm{a}$

$165.0 \pm 13.5 b$

$232.8 \pm 16.4 \mathrm{a}$

$34.9 \pm 0.4 b$

$38.4 \pm 1.3 \mathrm{ab}$

$41.1 \pm 2.0 \mathrm{a}$

$35.9 \pm 1.5 b$ 


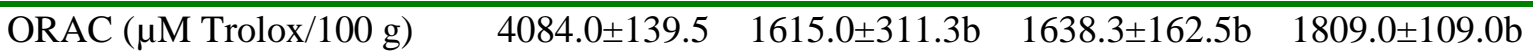

ENZYME ACTIVITY

$\mathrm{PME}(\mathrm{mmol} / \mathrm{min} / \mathrm{g})$

$23.3 \pm 1.0 \mathrm{a}$

$1.3 \pm 0.6 \mathrm{~b}$

$2.0 \pm 0.6 \mathrm{~b}$

$0.5 \pm 0.1 b$

PG $(\mathrm{mmol} / \mathrm{min} / \mathrm{g})$

$28.4 \pm 1.0 \mathrm{a}$

$21.1 \pm 2.1 b$

$25.6 \pm 3.4 \mathrm{ab}$

$26.3 \pm 2.0 \mathrm{ab}$

Values are means \pm standard deviation and the same letter following the value within the each raw indicates no significant difference at $\mathrm{p}<0.05, \mathrm{n}=3$, expressed on dry weight basis. 
Table 2: Pearson correlation between multiple quality parameters of tomato juice during long term storage at $28^{\circ} \mathrm{C}$ and $20^{\circ} \mathrm{C}$.

\begin{tabular}{|c|c|c|c|c|c|c|c|}
\hline Parameters & Colour & Carotenoids & Lycopene & $\begin{array}{l}\text { Ascorbic } \\
\text { acid }\end{array}$ & Total phenols & ABTS & ORAC \\
\hline Colour-redness & 1 & $0.80 * *$ & $0.85 * *$ & $0.70 * *$ & $0.70 * *$ & $0.80 * *$ & $0.33 * *$ \\
\hline Carotenoid & & 1 & $0.89 * *$ & & $0.90 * *$ & $0.91 * *$ & 0.12 \\
\hline Lycopene & & & 1 & $0.83 * *$ & $0.86 * *$ & $0.89 * *$ & 0.22 \\
\hline Ascorbic acid & & & & & $0.85^{* *}$ & $0.91 * *$ & 0.01 \\
\hline Total phenols & & & & & 1 & $0.87 * *$ & 0.05 \\
\hline ABTS & & & & & & 1 & 0.08 \\
\hline ORAC & & & & & & & 1 \\
\hline
\end{tabular}

Significant** at $\mathrm{p}<0.01$ 
Table 3: Effect of high pressure processing in comparison to thermal processing on phytochemical levels of tomato juice during storage at $28^{\circ} \mathrm{C}$ and $20^{\circ} \mathrm{C}$.

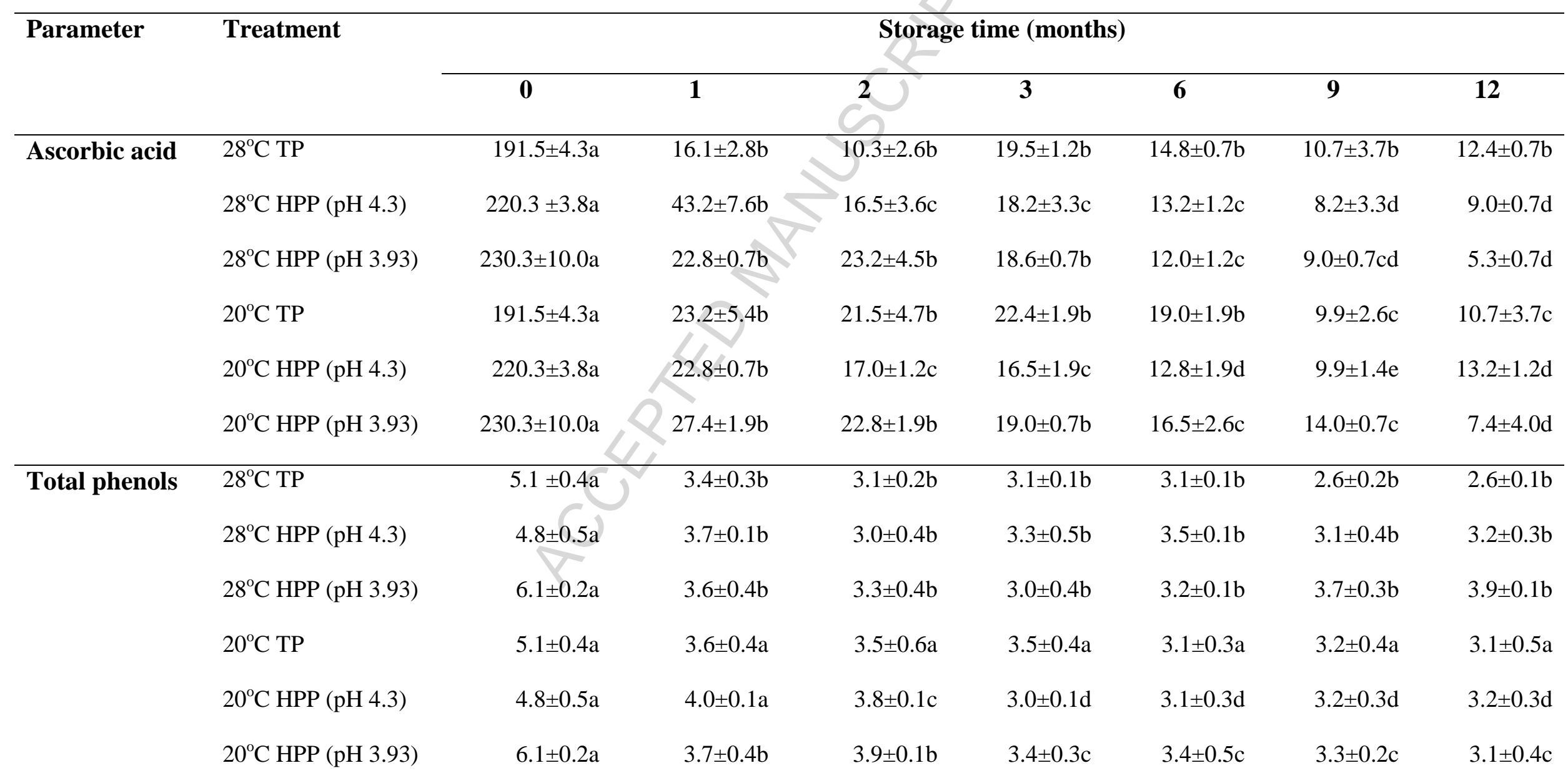




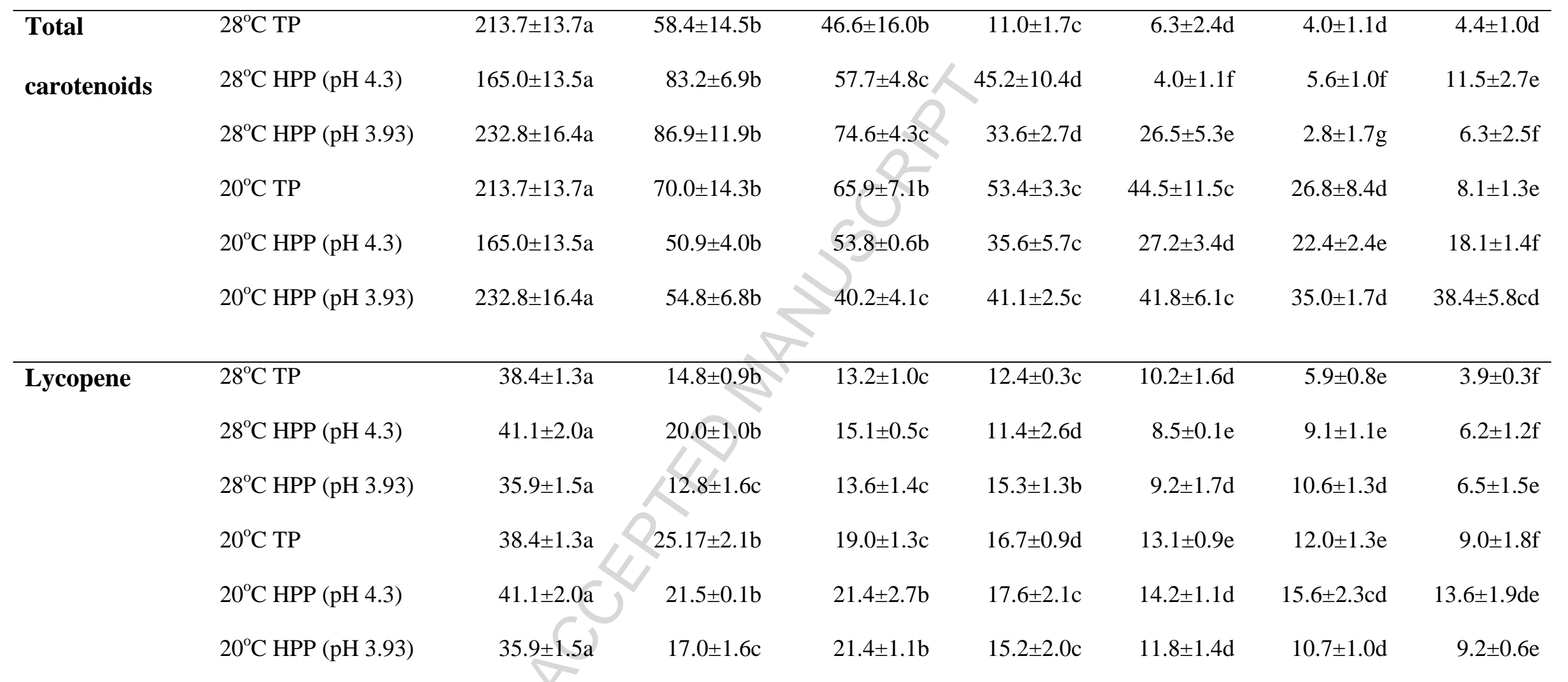

Values are means \pm standard deviation and the same letter following the value within the each raw is not significantly different as for the table above at $\mathrm{p}<0.05, \mathrm{n}=3$, expressed on dry weight basis. 
Table 4: First order kinetics rate constants $(k)$ and determination coefficients $\left(\mathrm{R}^{2}\right)$ for the degradation of the colour and micronutrients of processed tomato juice during storage at 20 ${ }^{\circ} \mathrm{C}$ and $28{ }^{\circ} \mathrm{C}$

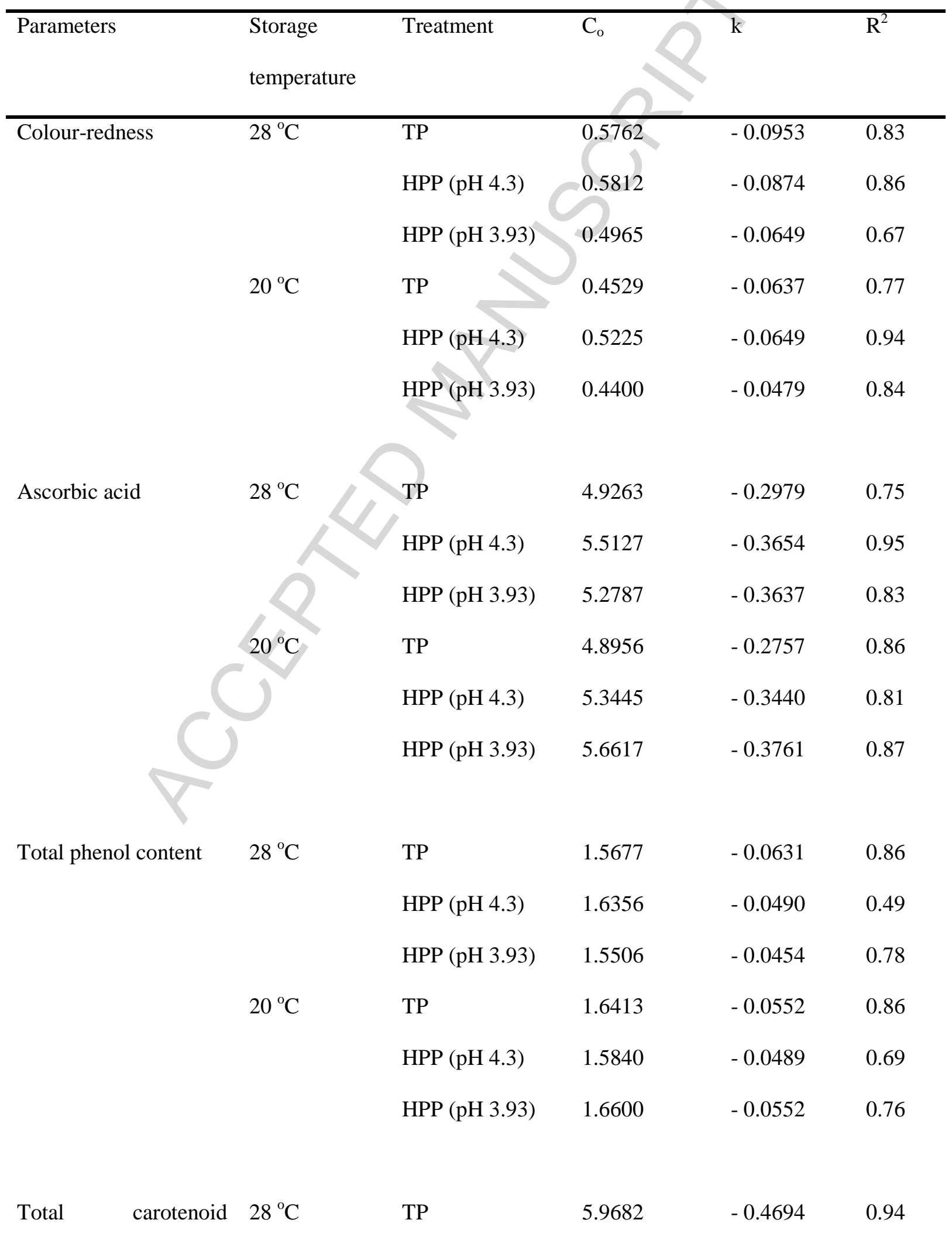




\begin{tabular}{|c|c|c|c|c|c|}
\hline \multirow[t]{2}{*}{ content } & & HPP (pH 4.3) & 5.7041 & -0.3739 & 0.75 \\
\hline & & HPP (pH 3.93) & 6.1000 & -0.4195 & 0.83 \\
\hline & $20{ }^{\circ} \mathrm{C}$ & TP & 5.5982 & -0.2783 & 0.85 \\
\hline & & HPP (pH 4.3) & 5.2986 & -0.2450 & 0.96 \\
\hline & & HPP (pH 3.93) & 5.318 & -0.2026 & 0.85 \\
\hline \multirow[t]{6}{*}{ Lycopene } & $28{ }^{\circ} \mathrm{C}$ & $\mathrm{TP}$ & 3.6702 & -0.2002 & 0.90 \\
\hline & & $\mathrm{HPP}(\mathrm{pH} 4.3)$ & 3.8937 & -0.2012 & 0.98 \\
\hline & & HPP (pH 3.93) & 3.7958 & -0.1819 & 0.91 \\
\hline & $20{ }^{\circ} \mathrm{C}$ & $\mathrm{TP}$ & 3.8168 & -0.1511 & 0.95 \\
\hline & & HPP (pH 4.3) & 3.6734 & -0.1121 & 0.92 \\
\hline & & HPP (pH 3.93) & 3.6117 & -0.1353 & 0.92 \\
\hline \multirow[t]{6}{*}{ ABTS } & & TP & 6.9779 & -0.1067 & 0.93 \\
\hline & & HPP (pH 4.3) & 6.9937 & -0.1208 & 0.82 \\
\hline & & HPP (pH 3.93) & 6.9750 & -0.1139 & 0.79 \\
\hline & & $\mathrm{TP}$ & 7.0190 & -0.1141 & 0.95 \\
\hline & & HPP (pH 4.3) & 7.0295 & -0.0999 & 0.85 \\
\hline & & HPP (pH 3.93) & 7.1366 & -0.1294 & 0.91 \\
\hline \multirow[t]{6}{*}{ ORAC } & $28{ }^{\circ} \mathrm{C}$ & $\mathrm{TP}$ & 7.5605 & -0.0139 & 0.07 \\
\hline & & HPP (pH 4.3) & 7.6238 & -0.0267 & 0.14 \\
\hline & & HPP (pH 3.93) & 7.6955 & -0.0467 & 0.21 \\
\hline & $20{ }^{\circ} \mathrm{C}$ & $\mathrm{TP}$ & 7.6483 & -0.0270 & 0.13 \\
\hline & & HPP (pH 4.3) & 7.6107 & -0.0258 & 0.15 \\
\hline & & HPP (pH 3.93) & 7.5236 & -0.0212 & 0.09 \\
\hline
\end{tabular}




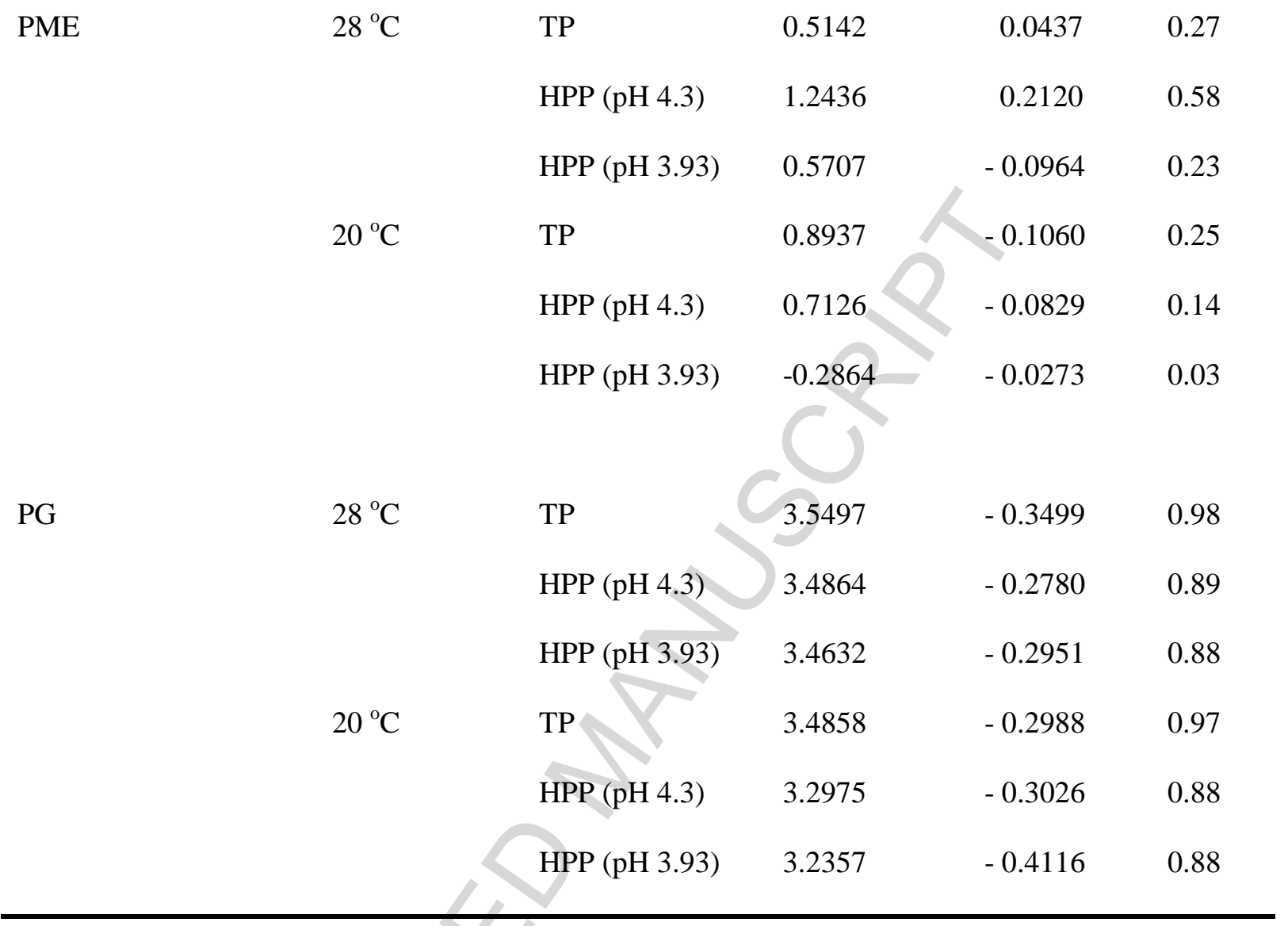




\section{Industrial relevance}

There is a demand for ambient stable tomato products, especially in some parts of the world, and current industrial practices (canning, pasteurisation) either compromise in product quality or require refrigeration conditions. High pressure processing have been investigated as milder technology, with a potential to deliver superior quality. The drawback is that is also requires chill storage. The results of this study show how quality parameters behave in a high pressured tomato product and pave the way for further development that could optimise this technology. This could be of economic importance for the tomato juice industry to develop new products stable in ambient temperatures and perhaps beneficial for cutting down the refrigeration costs under specific conditions. 


\section{Highlights}

- High pressure processing (HPP) on storage quality of tomato juice was studied.

- Lowering $\mathrm{pH}$ is beneficial in maintaining the colour of tomato juice during storage.

- Total quality of HPP tomato juice during the $1^{\text {st }}$ month is superior to conventional.

- Quality degradation of the juice during storage is higher at $28^{\circ} \mathrm{C}$ compared to $20^{\circ} \mathrm{C}$.

- Long term stability of processed tomato juice in ambient temperatures is challenging. 